\title{
Er Den internasjonale straffedomstolen afrikafiendtlig? Konfliktselektivitet og internasjonale straffedomstoler
}

Sofie A. E. Høgestøl ${ }^{\star}$, Stipendiat, Norsk senter for menneskerettigheter, Universitetet $i$ Oslo

Etter 13 år med virksomhet har Den internasjonale straffedomstolen (ICC) utelukkende straffeforfulgt konflikter i Afrika. Dette har ført til misnøye i regionen og kritikere anfører at domstolen har opptrådd partisk ovenfor afrikanske land i utvelgelsen av saker. Enkelte afrikanske ledere har i tillegg gått så langt som til å beskylde ICC for å være et verktøy for vestlig imperialisme. Denne artikkelen tar sikte på å drøfte i hvilken utstrekning kritikken er berettiget ved å analysere hvordan ICC har valgt konflikter i praksis, og ved å plassere debatten $\mathrm{i}$ den bredere diskusjonen om konfliktselektivitet og internasjonale straffedomstoler.

Nøkkelord: ICC • Afrika • Jurisdiksjon - Situasjoner

After 13 years of selecting situations, the International Criminal Court (ICC) has thus far only investigated conflicts in Africa. This has led to accusations of the Court having an African bias when selecting which conflicts to prosecute. Some African leaders have even accused the court of simply being a tool of western imperialism. This article attempts to determine the veracity of the Africa-bias allegations by examining the ICC's current practice of selecting situations, as well as by placing the debate within the broader context of international criminal tribunals and conflict selectivity.

Keywords: ICC • Africa • Jurisdiction • Situations

\section{Innledining}

Toppmøtet i Den afrikanske union fikk en dramatisk avslutning i juni 2015 da Sudans President, Omar al-Bashir, flyktet fra konferansen idet High Court i Johannesburg (en av landets ankedomstoler) skulle behandle en fengslingsbegiæring mot ham (Bowcott 2015). Bashir har vært siktet av Den internasjonale straffedomstolen (ICC)

^Korrespondanse: Sofie A. E. Høgestøl, Universitetet i Oslo. Email: s.a.hogestol@jus.uio.no 
for folkemord, forbrytelser mot menneskeheten og krigsforbrytelser siden 2009 (ICC 2009). Domstolen har utstedt to internasjonale arrestordrer mot Bashir og det var ikrafttredelsen av disse som dannet grunnlag for fengslingsbegjæringen. Som medlem av ICC er Sør-Afrika rettslig forpliktet til å utlevere personer som er siktet av domstolen. Like fullt uttalte den sør-afrikanske regjeringen at de ikke kom til å følge opp arrestordren og bisto tilsynelatende Bashir med å reise ut av landet. Dette på tross av et utreiseforbund som ankedomstolen hadde nedlagt mot Bashir mens de behandlet fengslingsspørsmålet (Al-Jazeera 2015).

At den sør-afrikanske regjerningen sannsynligvis har overkjørt sitt eget rettssystem i denne saken, vakte internasjonal oppmerksomhet. Men det var heller ikke uventet i lys av en skriftlig uttalelse som Den afrikanske nasjonalkongressen (ANC) - som har vært Sør-Afrikas regjerende parti siden apartheid - publiserte like før Bashir rømte landet. ANC anførte at Afrika har vært belemret med brorparten av ICCs strafforfølginger og konkluderte således med at ICC ikke lenger er «useful for the purposes for which it was intended» (Tisdall 2015). I oktober 2015 vedtok ANC at Sør-Afrika nå skal melde seg ut av ICC og president Zuma begrunnet avgjørelsen med at:

In the eyes of the African leaders, the ICC is biased ... Only Africans they are interested in. This is what has made Africa feel we need to relook at our participation. It looks like it is just meant for us. (Musker 2015)

Denne argumentasjonen er vanskelig å følge dersom man ikke har fått med seg debatten som har rast mellom ICC og en rekke afrikanske land i løpet av de siste årene. For ICC hadde innen utgangen av 2015 - etter 13 år med virksomhet - til gode å iverksette én eneste etterforskning utenfor Afrika. Domstolen har utelukkende straffeforfulgt afrikanere. Dette har ført til misnøye i regionen, og enkelte afrikanske ledere har gått så langt som til å beskylde ICC for å være et verktøy for vestlig imperialisme (Maunganidze \& Plessis 2015: 65).

Narrativet om ICC som en afrikafiendtlig domstol har nådd norsk offentlig debatt (Gullikstad 2015) og artikkelforfatteren har ved flere anledninger fått spørsmål om temaet fra journalister, studenter og akademikere. Denne artikkelen tar derfor sikte på å drøfte i hvilken utstrekning kritikken er berettiget, ved å gjennomføre en juridisk analyse av praksisen til ICC om valg av konflikter mellom 2002-2015. Ved å se nærmere på mekanismene som utløste eller «trigget» de konfliktene som domstolen etterforsket innen utgangen av 2015, vil artikkelen vise at afrikanske medlemsland i realiteten har vært viktige pådrivere $\mathrm{i}$ å sende sine egne konflikter til ICC, og at påtalemyndighetene ved domstolen i liten grad har brukt sin myndighet til å aktivt gå inn og velge hvilke konflikter ICC burde etterforske.

For å gi kontekst til en mulig konfliktselektivitet ved ICC åpner artikkelen med en kort historisk gjennomgang av internasjonale straffedomstoler og hvordan slike domstoler tradisjonelt har vært begrenset til å straffeforfølge spesifikke konflikter. Neste del gir en gjennomgang av mandatet til ICC og viser at også denne domstolen har blitt skapt med begrensninger som gjør den selektiv i valg av konflikter. Deretter 
presenteres en empirisk gjennomgang av ICCs praksis på valg av konflikter mellom 2002-2015, som undersøker om der fins belegg for å hevde at domstolen aktivt har vist en form for afrikafiendtlighet i måten den har valgt konflikter. Siste del før konklusjonen vil bygge på funnene fra den empiriske analysen og diskutere hvorvidt der finnes indikasjoner på at ICC heller har utøvd en slags passiv selektivitet i valg av konflikter.

\section{Permanente og midlertidige internasjonale straffedomstoler}

Før man kan ta for seg valg av konflikter ved ICC, er det verdt å reflektere over hvordan internasjonale straffedomstoler tradisjonelt har blitt tildelt konfliktene de skal etterforske. Internasjonale straffedomstoler som ICC har mandat til å straffeforfølge enkeltpersoner for krigsforbrytelser, folkemord og forbrytelser mot menneskeheten. De er kort sagt spesialdomstoler opprettet via internasjonale mekanismer, som opererer utenfor det nasjonale rettssystemet og tar for seg grove internasjonale forbrytelser.

Verdenssamfunnet har opprettet seks slike rettsinstitusjoner i løpet av de siste tyve årene og av disse er ICC den første og til nå eneste permanente internasjonale straffedomstolen. De resterende fem har vært midlertidige ad hoc-domstoler, skapt i regi av FN for å straffeforfølge spesifikke konflikter. FNs krigsforbrytertribunal for det tidligere Jugoslavia (ICTY) er kanskje den mest kjente av disse midlertidige domstolene, og var den første internasjonale straffedomstolen stiftet etter Nürnbergprosessen. Domstolen ble opprettet i 1993 av Sikkerhetsrådet for å straffeforfølge menneskene ansvarlig for de grove internasjonale forbrytelsene forvoldt $i$ det som da var Jugoslavia (ICTY 1993). Mandatet til ICTY rommer således ikke forbrytelser uten tilknytning til Jugoslaviakonflikten, og må da i likhet med de andre ad hoc-domstolene kategoriseres som en konfliktspesifikk domstol. Ettersom ad hoc-institusjonene er konfliktspesifikke, er de også midlertidige domstoler som avvikles etter at de har gjennomført rettsakene og etterforskningen knyttet til sin konflikt.

ICC er derimot, i kraft av å være en permanent domstol med medlemsland, ikke begrenset til én enkeltkonflikt. Roma-vedtektene danner det juridiske grunnlaget for ICC og de ble vedtatt ved en stor diplomatisk konferanse i 1998 (Romakonferansen 1998). ICC åpnet dørene sine i 2002 og inkluderer i dag med sine 123 statsparter (medlemsland) to tredjedeler av verdens stater. Det at ICC er skapt og styrt av sine medlemsland - og ikke i regi av FN slik som ad hoc-domstolene - gir domstolen flere unike trekk. Muligheten til å etterforske og straffeforfølge et multiplum av konflikter er kanskje den viktigste av disse egenskapene. Visjonen for en permanent internasjonal straffedomstol var nettopp å skape en domstol med et bredt mandat til å straffeforfølge nye tilfeller av grove internasjonale forbrytelser, i det de oppstår (Schabas 2015: 373). Nürnberg- og ad hoc-domstolene ble grunnlagt i etterkant av konfliktene de var satt til å etterforske, og er således institusjoner bygget på et tilbakevirkende rettsgrunnlag. Fra et juridisk perspektiv reiser dette ubehagelige 
problemstillinger knyttet til tilbakevirkende kraft, samt at det også har ført til at ad hoc domstolene har blitt beskyldt for å bedrive seierherrens justis.

Da fengselspsykiateren ved Nürnberg, G.M. Gilbert, spurte Hermann Göring om han kunne signere en kopi av tiltalen mot han - som en suvenir - skal Göring ha signert og skrevet "The victor will always be the judge, and the vanquished the accused» (Gilbert 1947: 4). Siden den gang har fremstillingene av internasjonale strafferettsdomstoler som seierherrens justis florert. Debatten fornyet seg i 1993 da Sikkerhetsråd opprettet ICTY, etter at amerikanske diplomater hadde drevet omfattende lobbyvirksomhet for en slik domstol (Scheffer 2012: 15-45). En av de siktede serbiske militantene fra Jugoslaviakonflikten skal ha uttalt at «I will go to a war crimes tribunal when Americans are tried for Hiroshima, Nagasaki, Vietnam, Cambodia, Panama!» (Bass 2000: 8). Det kan diskuteres i hvilken grad seierherrens justis er en treffende beskrivelse av alle ad hoc-domstolene, men det er vanskelig å argumentere mot at disse rettsinstitusjonene har blitt brukt svært selektivt.

\section{Konfliktselektiviteten i det internasjonale strafferettssystemet}

FN har som nevnt opprettet fem ad hoc-domstoler siden andre verdenskrig, og disse domstolene har omfattet følgende konflikter: Jugoslaviakrigen, folkemordet i Rwanda, borgerkrigen i Sierra Leone, folkemordet i Kambodsja, og terrorangrepet som drepte Rafic Hariri (tidligere libanesisk statsminister) i Libanon. ${ }^{1}$ Dette er altså konflikter som har funnet sted mellom 1975 og 2009. Sett ut i fra dette perspektivet har internasjonale straffedomstoler alltid vært selektive i valg av konflikter. For innenfor tidsspennet 1975-2009 er det flere alvorlige tilfeller av massevold som ikke er representert av de fem utvalgte konfliktene til ad hoc-domstolene. Eksempelvis krigsforbrytelsene begått under Vietnamkrigen, bruk av kjemiske våpen i Iran-Irakkrigen, kinesiske forbrytelser i Tibet, borgerkrigene i Burundi og Angola, samt koalisjonsstyrkenes okkupasjon under Irak-krigen. Felles for alle eksemplene er at de enten har involvert mektige stater, eller at de er konflikter som i liten grad fanget internasjonal oppmerksomhet.

Gitt at de midlertidige internasjonale straffedomstolene var skapt i regi av FN under tilsyn av Sikkerhetsrådet, er det ikke overaskende at konflikter som har involvert permanente medlemmer av rådet - eller deres interesser - i liten grad har blitt gjenstand for en internasjonal straffedomstol. Ser man nærmere på den politiske konteksten som muliggjorde opprettelsen av ad hoc-domstolene, er det tydelig at de to avgjørende elementene har vært samarbeidsviljen til Sikkerhetsrådet og konfliktens synlighet. Ad hoc-domstolene ble dannet som et resultat av omfattende diplomatiske prosesser knyttet til konflikter med mye internasjonal oppmerksomhet (Scheffer 2012). Borgerkrigen i Sierra Leone skiller seg eksempelvis ikke vesentlig fra borgerkrigene i Burundi. Men der sistnevnte er lite kjent internasjonalt, ble borgerkrigen i Sierra Leone verdenskjent for bruk av barnesoldater og ikke minst

\footnotetext{
${ }^{1}$ Det internasjonale krigsforbrytertribunalet for det tidligere Jugoslavia (1993), Det internasjonale tribunalet for Rwanda (1994), Spesialdomstolen for Sierra Leone (2002), Røde-Khmer Tribunalet (2006) og Spesialtribunalet for Libanon (2009).
} 
bloddiamanter (Campell 2004). En internasjonal straffedomstol for Sierra Leone ble følgelig grunnlagt i 2002, på samme tidspunkt som bruk av barnesoldater i borgerkrigen i Burundi eskalerte (Ngaruko \& Nkurunziza 2005: 49).

På den andre siden finner man konflikter som fort kunne vært gienstand for en internasjonal straffedomstol, men som har involvert én eller flere av verdens stormakter. Konfliktene i nabolandene Vietnam og Kambodsja på 70-tallet har tette koblinger, likefult er det sistnevnte som har fått en internasjonal straffedomstol. Rettsakene mot lederne i Røde Khmer-regimet pågår i skrivende stund, 40 år etter forbrytelsene (ECCC 2010a). Et lignende rettsoppgjør for Vietnamkrigen er nærmest utenkelig gitt USAs posisjon i Sikkerhetsrådet.

Når internasjonale straffedomstoler opprettes selektivt kun for å etterforske et mindretall av internasjonale forbrytelser, bryter det med den allmenne rettsoppfatning av rettsordenen som nøytral og likegjeldende for mektige stater så vel som for andre. Håpet var at en permanent internasjonal straffedomstol skulle dempe denne skjevheten ved å gi ICC et mandat som gjorde det mulig for domstolen å straffeforfølge flere konflikter samtidig. Nestoren i internasjonal strafferett, Antonio Cassese, oppsumerte forventingene til ICC som følger: «For the first time in history, a truly international criminal tribunal was set up with a potentially universal scope and charged with dispensing justice not on an ad hoc, i.e. selective basis» (Cassese 2006: 434). Men etter 13 år med virksomhet er ICC nå altså anklagd for nettopp å ha vært selektiv i valg av konflikter, ved å utelukkende straffeforfølge afrikanere.

\section{Mandatet till ICC}

For å kunne vurdere om ICC har vært partisk overfor afrikanske land i valg av saker, må man først ta for seg mandatet domstolen har til å etterforske konflikter. Per desember 2015 hadde ICC åpnet etterforskninger i ni «situasjoner», ${ }^{2}$ begrepet domstolen bruker for å betegne en konflikt eller hendelse av internasjonale forbrytelser. Ettersom ICC både er den første permanente internasjonale straffedomstolen og den første domstolen som ikke er begrenset til en gitt konflikt, eksisterer det en utbredt oppfatning om at ICC har hjemmel til å ta for seg alle verdens konflikter. Men det er ikke tilfelle, ettersom ICC har et begrenset mandat.

Jurisdiksjon er et juridisk begrep som litt forenklet beskriver kompetansen eller mandatet en domstol har til å behandle saker (Gisle 2009). Uten jurisdiksjon kan en domstol verken igangsette etterforskning, ta ut siktelser eller avsi en dom. Med universell jurisdiksjon hadde ICC hatt hjemmel til å etterforske alle internasjonale forbrytelser, uansett hvor de finner sted i verden. Men ICC har i likhet med de fleste andre internasjonale domstoler et avgrenset mandat som gir en begrenset jurisdiksjon. For det første har ICC et tidsbegrenset mandat, hvor domstolen kun har jurisdiksjon til

\footnotetext{
${ }^{2}$ Nettsiden til ICC oppdaterer til en hver tid statusen på etterforskninger og situasjoner (http:// www.icc-cpi.int/Pages/default.aspx), men domstolen rapporterer også offisielt til FNs Generalforsamling én gang i året og gjengir da hvilke etterforskninger de jobber med (FNs Generalforsamling, 2014: 9-16).
} 
å etterforske saker som har funnet sted etter 1. juli 2002, da vedtektene til domstolen tråde i kraft (Roma-vedtektene artikkel 11).

Videre er ICCs jurisdiksjon hovedsakelig samtykkebasert, hvor land frivillig påtar seg de rettslige forpliktelsene som følger av enten å være medlem av domstolen eller å ha gitt ICC midlertidig tillatelse til å etterforske saker. Den stedlige eller territorielle jurisdiksjonen til ICC er i utgangspunktet begrenset til domstolens medlemsland (Roma-vedtektene artikkel 12). Domstolen har med andre ord et mandat til å etterforske saker som har funnet sted på territoriet til de 123 landende som er medlem av domstolen. I tillegg har ICC jurisdiksjon over statsborgerne fra medlemsland. I praksis betyr det at domstolen også kan etterforske forbrytelser som har skjedd på territoriet til et land som ikke er medlem av domstolen, så lenge forbrytelsen er begått av en person som er statsborger av et medlemsland. Roma-vedtektenes artikkel 12(3) åpner dessuten for at stater som ikke er medlem av domstolen kan gi ICC midlertidig hjemmel til å etterforske forbrytelser som har funnet sted på deres territorium innenfor en spesifisert tidsramme.

Det er ett unntak fra denne hovedregelen, Sikkerhetsrådet kan via Romavedtektenes artikkel 13(b) fatte vedtak om å henvise konflikter til ICC, uavhengig av hvor konflikten har funnet sted (Roma-vedtektene artikkel 13). Gjennom slike henvendelser kan ICC få en form for universell jurisdiksjon, da Sikkerhetsrådet kan velge å henvise en konflikt til domstolen i et land som ikke er medlem.

\section{Medlemsland}

Når ICCs hjemmel til å etterforske situasjoner er såpass tett bundet til domstolens medlemsland, er det betimelig å se nærmere på hvem som er medlem. Som nevnt har ICC 123 medlemsland, etter at Palestina ble medlem i 2015 (Høgestøl 2015). Fordelt på geografisk tilhørighet har domstolen 34 medlemsland fra Afrika, 27 fra Latin-Amerika, 25 fra Vest Europa og Nord Amerika, 19 fra Asia og 18 fra ØstEuropa (ICC 2016). De afrikanske landene er således den største medlemsgruppen til ICC og deres tidlige entusiasme for domstolen og ratifisering av Roma-vedtektene spilte en avgjørende rolle for ICC i domstolens oppstartsfase (Chigara \& Nwankwo 2015: 253; Mills 2012: 405).

I motsetning til hovedandelen av europeiske, afrikanske og latinamerikanske stater, glimrer flere mektige land med sitt fravær fra ICCs medlemsliste. Av Sikkerhetsrådets permanente medlemmer er det kun England og Frankrike som er medlem av domstolen. Russland, Kina og USA er ikke medlemmer. Det skaper en tankevekkende dynamikk når flertallet av Sikkerhetsrådets permanente medlemmer har valgt å stå utenfor ICCsamarbeidet, men samtidig har muligheten til å referere situasjoner $\mathrm{i}$ andre land til domstolen. USA og Kina utmerker seg spesielt fordi de begge engasjerte seg aktivt $i$ forhandlingene av Roma-vedtektene under Romakonferansen (Jia 2006; Scheffer 1999), uten at de har vært villige til å ratifisere vedtektene i etterkant.

I likhet med de tre Sikkerhetsrådsmaktene har en rekke regionale makter også vegret seg fra å bli medlem. Disse inkluderer sentrale aktører som Iran, Saudi Arabia, Tyrkia, Israel, Pakistan og India. Dette betyr i korte trekk at brorparten av verdens mektigste stater står utenfor domstolens mandat. Flere av de nevnte statene er for 
øyeblikket sentrale aktører i pågående strider. Syria (som heller ikke er medlem av ICC) er kanskje det mest aktuelle av disse konfliktene. Med mindre Sikkerhetsrådet velger å henvise konfliktene til disse mektige ikke-medlemslandene, vil de sannsynligvis forbli utenfor jurisdiksjonen til ICC.

\section{Triggermekanismer og konfliktselektivitet}

Videre er det heller ikke slik at aktoratet ved ICC automatisk har autoriteten til å etterforske internasjonale forbrytelser så snart det oppstår en konflikt i et medlemsland. For at påtalemyndighetene skal kunne igangsette en ny etterforskning må jurisdiksjonen til ICC først 'trigges' (Olásolo 2005).

Det finnes tre måter å trigge en formell etterforskning. Den første er ved at et medlemsland henviser en medlemslandsituasjon til domstolen via Roma-vedtektenes artikkel 13(a). Den andre måten er at domstolens sjefsanklager på eget initiativ (eller proprio motu som det heter i Roma-vedtektenes artikkel 15), søker om tillatelse fra forkammeret til å igangsette en formell etterforskning $\mathrm{i}$ en situasjon som faller inn under jurisdiksjonen til ICC. Sist men ikke minst kan en etterforskning trigges gjennom en sikkerhetsrådshenvendelse - og i dette tilfelle kan som nevnt også konflikter i ikke-medlemsland land bli henvist til ICC.

Begrensningene i mandatet og triggermekanismene innebærer at også ICC er utformet til å være selektiv i valg av konflikter. For det første er domstolen selektiv ettersom ikke alle konflikter faller inn under domstolens jurisdiksjon. Videre medfører triggermekanismene at det heller ikke er noen automatikk i at ICC etterforsker en konflikt som faller inn under mandatet; situasjoner må trigges før det utløses en etterforskning. ICC har i likhet med de fleste internasjonale institusjoner et stramt budsjett og triggermekanismene hindrer således at ICC blir nedrent av et uhåndterbart antall konflikter. ${ }^{3}$ Triggermekanismene åpner heller for at domstolen kan prioritere noen konflikter over andre, uten at de behøver å rettferdiggiøre dette valget overfor sine medlemsland. Der hverken medlemslandet eller Sikkerhetsrådet har henvist en konflikt, står sjefsanklageren ved ICC fritt til å vurdere om hun ønsker å bruke sin proprio motu makt til å trigge åpningen av en ny etterforskning. I slike tilfeller har påtalemyndigheten derfor et handlingsrom til å velge om den ønsker å åpne en ny situasjon, eller om den heller ønsker å prioritere ressurser på en annen konflikt (Smeulers, Weerdesteijn et al. 2015: 3). Dette handlingsrommet og det skjønnet aktoratet følgelig har til å velge mellom konflikter, har på mange måter vært det mest kontroversielle aspektet ved ICC. Som deGuzman skriver:

No aspect of the ICC's work has been more controversial to date than its decisions about which situations and cases to prosecute. Every selection decision the Court makes is scrutinized, and many have given rise to strong criticisms. Such expressions of disapproval have come from each of the ICC's primary evaluative audiences - states, NGOs, communities most affected by the ICC's work, academics, and the global community generally. (DeGuzman 2012: 271)

\footnotetext{
${ }^{3}$ Påtalemyndigheten ved ICC har ved flere anledninger etterlyst en budsjettøkning for å finansiere flere etterforskninger og rettssaker. Domstolen har eksempelvis søkt om en økning på 17\% til 2016 budsjettet (Jakobssen 2015).
} 
Av denne kritikken er det påstanden om at ICC har vært partisk overfor afrikanske medlemsland i måten domstolen har valgt konflikter som har vært mest utbredt (Mills 2012) (Chigara \& Nwankwo 2015; Smeulers, Weerdesteijn et al. 2015; Jalloh 2009). Denne kritikken står i sterk kontrast til hvor entusiastiske og støttende afrikanske land var da ICC ble ratifisert.

For å kunne vurdere i hvilken grad valg av konflikter synes å ha vært praktisert partisk av ICC vis-à-vis afrikanske land, må man foreta en grundig analyse av ICCs praksis. Denne analysen vil ta for seg triggermekanismene som utløste etterforskningen og ha sitt grunnlag $\mathrm{i}$ det juridiske rammeverket som påtalemyndigheten må forholde seg til når den har åpnet etterforskninger.

\section{En analyse av ICCs praksis fira 2002-2015}

ICC åpnet dørene i 2002 og i løpet av sine første 13 år med virksomhet kan valg av konflikter oppsummeres som følger: Av ni situasjoner har fem blitt henvist av medlemslandet selv, to har blitt sendt til ICC fra Sikkerhetsrådet og to har blitt åpnet av sjefsanklageren ved domstolen (FNs generalforsamlingsrapport 2014: 9-16).

Tre observasjoner kan trekkes fra tallene. Før det første kommer det tydelig frem at Sikkerhetsrådet i liten grad har benyttet seg av sin mulighet til å henvise saker til ICC. I kontrast med antall konflikter som potensielt kunne ha blitt sendt til ICC i løpet av de siste 10 årene har Sikkerhetsrådet kun henvist to situasjoner til domstolen. Ettersom dette er den eneste mekanismen som muliggjør straffeforfølgning av konflikter i land som faller utenfor domstolens alminnelige jurisdiksjon, medfører det at ICC i liten grad har hatt mulighet til å ta for seg disse konfliktene.

For det andre har ICC til gode å få en situasjon henvist fra et medlemsland utenfor Afrika. Det er utelukkende afrikanske stater som på eget initiativ har valgt å henvise sine egne konflikter til domstolen. Denne trenden forsterker seg ytterligere dersom man ser på konfliktene som har vært eller var under innledende gransking innen utgangen av 2015. Før ICC åpner en formell etterforskning, iverksetter påtalemyndigheten en innledende gransking hvor de verifiserer at konflikten faller inn under domstolens mandat og at det ikke eksisterer grunnlag for at den burde avvises

Tabell 1. Situasjoner under etterforskning per desember 2015

\begin{tabular}{lc}
\hline Situasjoner under etterforskning & Triggermekanisme \\
\hline Kongo (2004) & Medlemsland \\
Uganda (2004) & Medlemsland \\
Sudan (2005) & Sikkerhetsrådet \\
Sentralafrikanske republikk 1 (2007) & Medlemsland \\
Kenya (2010) & Sjefsanklageren \\
Libya (2011) & Sikkerhetsrådet \\
Elfenbeinskysten (2011) & Sjefsanklageren \\
Mali (2013) & Medlemsland \\
Sentralafrikanske republikk 2 (2014) & Medlemsland \\
\hline
\end{tabular}


(Office of the Prosecutor ICC 2014a). Innledende gransking er således undersøkelsesstadiet som kommer før etterforskning. Men en konflikt er likevel ikke formelt valgt før det åpnes for etterforskning - det er først da sjefsanklageren kan ta ut siktelser og straffeforfølge enkeltpersoner.

Innen utgangen av 2015 var åtte situasjoner under innledende gransking. Domstolens påtalemyndighet hadde valgt å avslutte fire innledende granskinger uten å gå videre med en etterforskning (Office of the Prosecutor ICC 2015b).

Av de 12 konfliktene som er eller har vært under innledende gransking, er det kun situasjonen i Komorene, Hellas og Kambodsja som har blitt henvist av et medlemsland. Situasjonen ble sendt til ICC av Komorene, uten hjelp fra Hellas eller Kambodsja (ICC 2015a). Dermed er også denne situasjonen trigget av et afrikansk medlemsland. De 11 resterende situasjonene er under innledende gransking på initiativ fra domstolens påtalemyndighet - og er med unntak av Nigeria og Guinea, konflikter som har funnet sted $i$ land utenfor Afrika. Man kan da merke seg at myndighetene i disse 11 statene har latt være å sende situasjonen sin til ICC, selv om sjefsanklageren mener at det var grunnlag for å tro at straffbare hendelser har funnet sted.

Tabell 2. Konflikter under innledende gransking per desember $2105^{4}$

\begin{tabular}{lc}
\hline Konflikter under innledende gransking & Triggermekanisme \\
\hline Colombia (2004) & Sjefsanklageren \\
Afghanistan (2007) & Sjefsanklageren \\
Georgia (2008) 5 & Sjefsanklageren \\
Guinea (2009) & Sjefsanklageren \\
Nigeria (2010) & Sjefsanklageren \\
Irak (2014 og 2006) & Sjefsanklageren \\
Ukraina (2014) & Sjefsanklageren \\
Palestina (2015) & Sjefsanklageren \\
\hline
\end{tabular}

Tabell 3. Avsluttede innledende granskinger per desember 2015

\begin{tabular}{lr}
\hline Avsluttet innledende gransking & Triggermekanisme \\
\hline Korea & Sjefsanklageren \\
Venezuela & Sjefsanklageren \\
Komorene, Hellas og Kambodsja & Medlemsland \\
Honduras & Sjefsanklageren
\end{tabular}

\footnotetext{
${ }^{4}$ Den mest oppdaterte listen av situasjoner finner man nok en gang på ICCs nettsider, men aktoratet rapporterer også om situasjonene under innledende gransking hvert år og her kan man finne en mer detaljert analyse av sakene (Office of the Prosecutor 2014a).

${ }^{5}$ I oktober 2015 sendte påtalemyndighetene en søknad til forhørsdommerne ved ICC om å åpne en etterforskning i Georgia (ICC 2015b). Ettersom saken ikke formelt hadde blitt åpnet for etterforskning innen utgangen av 2015 er den fortsatt kategorisert som en innledende gransking.
} 
Den tredje og siste observasjonen er at sjefsanklageren ved ICC har vært relativt tilbakeholden med å bruke sin makt til å etterforske situasjoner på eget initiativ. Det er bare to av ni situasjoner under etterforskning som har vært igangsatt av påtalemyndigheten. I likhet med Sikkerhetsrådet er der flere enn to konflikter som påtalemyndigheten ved ICC i teorien kunne ha valgt å etterforske i løpet av de siste ti årene. Dette underbygges av at nesten alle konfliktene under innledende gransking har blitt initiert av sjefsanklageren og flere av disse konfliktene har vært til gransking i 6-7 år. Det er interessant å merkes at ved slutten av 2015 hadde sjefsanklageren initiert 14 innledende granskinger, mot at bare to hadde blitt åpnet for etterforskning.

\section{ICC har i liten grad aktivt valgt situasjonene den behandler}

Ut fra ICCs praksis har det blitt trukket tre generelle observasjoner, men empirien synes også å fremheve en ytterligere trend: I løpet av sine første 13 år med virksomhet hadde domstolen i liten grad aktivt gått inn og valgt konfliktene til etterforskning hos påtalemyndigheten. Brorparten av situasjonene var heller blitt henvist til ICC av enten et medlemsland eller Sikkerhetsrådet. For å kunne sette denne trenden i kontekst er det nødvendig å se nærmere på noen av situasjonene som har blitt trigget for etterforskning.

\section{Konflikter fra medlemsland}

Ettersom flertallet av konfliktene ved ICC innen tidsrommet 2002-2015 var henvist til domstolen fra medlemsland, er det logisk å starte med disse sakene. Seks situasjoner ble henvist til domstolen fra medlemsland: to fra Den sentralafrikanske republikk og en hver fra Congo, Uganda, Mali og Komorene. Av disse sakene er det bare sistnevnte som har blitt henlagt av sjefsanklageren.

Påtalemyndigheten ved ICC er i utgangspunktet ikke forpliktet til å åpne en etterforskning når de mottar en henvendelse fra et medlemsland eller Sikkerhetsrådet. Henvendelsen trigger jurisdiksjonen til domstolen og gir påtalemyndighet hjemmel til å åpne en etterforskning, men sjefsanklageren kan etter å ha gransket situasjonen konkludere med at den burde henlegges så fremt konflikten faller utenfor mandatet til ICC. Dersom den bestemmer seg for å henlegge situasjonen må påtalemyndigheten offentliggjøre en begrunnelse som sendes til forhørsdommerne ved ICC (Roma-vedtektene artikkel 53(1)). Staten som henviste saken kan da be forhørsdommerne om å gjennomgå henleggelsen (Roma-vedtektene artikkel 53(3)). Denne henleggelsesmekanismen gjenspeiler at det foreligger en presumsjon for å etterforske når et medlemsland eller Sikkerhetsrådet har henvist situasjonen til ICC. Som det står nedfelt i artikkel $53(1)$ av Roma-vedtektene så skal sjefsanklageren «iverksette en etterforskning, med mindre han eller hun finner at det ikke er rimelig grunnlag for å gå videre med saken i henhold til disse vedtekter».

Denne presumsjonen styrkes nå ytterligere gjennom forhørsdommernes behandling av Komorene-situasjonen, som omfatter det som angivelig skal være israelske krigsforbrytelser mot to skip flagget til Komorene, Hellas og Kambodsja i 2010. Skipene var del av en humanitær båtkonvoi («flotilla») på vei til Gaza med forsyninger, 
da de ifølge Komorenes henvisning til ICC skal ha blitt angrepet av israelsk militær. Ni personer ombord skal ha mistet livet som følge av militæraksjonen (Komorene 2013). Påtalemyndigheten åpnet en innledende gransking i saken, men konkluderte i 2014 at situasjonen ikke innfridde kravene etter Roma-vedtektene. Aktoratet mente at selv om Israels handlinger kunne anses å være en krigsforbrytelse, var omfanget av hendelsen av en slik beskjeden størrelse at det ikke innfridde kravet i artikkel 17(1)(d) om å være 'tilstrekkelig alvorlig' (Office of the Prosecutor ICC 2014b). Med andre ord var en straffesak som omfattet 9 dødsfall ikke alvorlig nok til å utløse en ICC-etterforskning. I januar 2015 klagde Komorene på henleggelsen og i sin kjennelse om situasjonen var forhørsdommerne ved ICC tydelige på at aktoratet hadde henlagt situasjonen på sviktende juridisk grunnlag (ICC 2015a: para. 49). Forhørsdommerne var uenige i aktoratets tolkning av 'tilstrekkelig alvorlig' og beordret dem å se på saken på nytt. Ved utgangen av 2015 lå situasjonen fortsatt til revurdering hos påtalemyndigheten.

Komorene-situasjonen er som sagt den første og til nå eneste situasjonen hvor sjefsanklageren har forsøkt å henlegge en sak som har blitt henvist fra Sikkerhetsrådet eller et medlemsland. Kjennelsen til forhørsdommerne understreker således at situasjonen må falle tydelig utenfor mandatet til ICC for at den skal kunne bli henlagt når den er trigget av en henvendelse:

If the information available at the pre-investigative stage allows for reasonable inferences that at least one crime within the jurisdiction of the Court has been committed and that the case would be admissible, the Prosecutor shall open an investigation... (ICC 2015a: para. 13)

Kjennelsen til forhørskammeret viser at dersom Sikkerhetsrådet eller et medlemsland henviser en sak til ICC og påtalemyndigheten finner det synlig at en eller flere internasjonale forbrytelser har blitt forvoldt i konflikten, så skal påtalemyndigheten åpne en etterforskning. Denne tilnærmingen til henvendelser er også i tråd med domstolens formål. ICC har blitt skapt for å straffeforfølge grove internasjonale forbrytelser, det hadde da vært underlig dersom aktoratet kunne avise legitime forespørsler om etterforskning fra sine egne medlemsland.

Dette betyr at hovedspørsmålet aktoratet måtte ta stilling til da de vurderte henvendelsene fra Mali, Kongo, Sentralafrikanske Republikk og Uganda var om det hadde blitt begått internasjonale forbrytelser i tråd med mandatet til ICC i løpet av disse konfliktene. For samtlige av konfliktene er svaret ja. Kongolesiske myndigheter spurte eksempelvis ICC om hjelp til å straffeforfølge krigsforbrytelser i Ituri og SørKivu regionen av landet, hvor krigshandlingene var så alvorlige at de ble beskrevet som «boardering on genocide» (Bruke-White 2005: 563). I Uganda henviste presidenten forbrytelsene som ble forvoldt av «Lord's Resistance Army» (LRA) under borgerkrigen (ICC 2004). Greenawalt beskriver LRAs bruk av barnesoldater slik:

Under Kony's leadership, the LRA has been responsible for the forced abduction, conscription, and abuse of tens of thousands of children, who at times have comprised as much as eighty-five percent of the group's forces. Reports paint a grim picture of these abductees' treatment (Greenawalt 2009: 112). 
I Mali trigget myndighetene en ICC-henvendelse for å få bistand til å etterforske forbrytelsene mot menneskeheten de påstår har skjedd som en del av et islamistisk opprør nord i landet (Mali 2012). Den sentralafrikanske republikk har på sin side vært i en eskalerende voldsspiral som har ført til to ICC-henvendelser fra landets myndigheter. En FN-rapport fastslo i desember 2014 at etnisk rensning har forekommet i løpet av konflikten og at det kan foreligge indikatorer på folkemord (FNs sikkerhetsrådrapport 2014: para. 45-50).

I lys av alvorsgraden til de internasjonale forbrytelsene som er under gransking $\mathrm{i}$ disse konfliktene hadde det vært oppsiktsvekkende av påtalemyndigheten ved ICC å henlegge etterforskningene. ${ }^{6}$ Det hadde sannsynligvis heller ikke vært juridisk mulig med tanke på forhørsdommernes kjennelse i Komorene-situasjonen. Sjefsanklageren har således ikke valgt konfliktene som har blitt henvist fra medlemslandene; aktoratet har vært pliktige til å etterforske dem i tråd med Roma-vedtektene.

\section{Sikkerhetsrådshenvendelser}

I likhet med henvisninger fra medlemsland foreligger det en presumsjon om at domstolen skal åpne etterforskninger som følge av en sikkerhetsrådshenvendelse. Sudan var som nevnt den første konflikten som ble gienstand for en henvendelse fra Sikkerhetsrådet i 2005. Det var også denne situasjonen som fikk fart på spliden mellom domstolen og Den afrikanske unionen (AU).

Ved å vedta sikkerhetsrådsresolusjon 1593 skrev Sikkerhetsrådet seg inn i historiebøkene da de i mars 2005 ba sjefsanklageren ved ICC om å granske en situasjon utenfor domstolens territorielle mandat (FNs sikkerhetsrådsresolusjon 2005). Bakgrunnen for sikkerhetsrådshenvendelsen var den humanitære katastrofen i Darfur som startet i 2003 med væpnede sammenstøt mellom opprørsgrupper som beskyldte den sudanske regjeringen for å ha marginalisert afrikanske minoritetsgrupper i Sudan, og militærgrupper knyttet til myndighetene (Udombana 2005: 6). Innen begynnelsen av 2005 hevdet støttespilleren til opprørsgruppene at sundanesiske myndigheter var ansvarlig for folkemord og en ekspertgruppe oppnevnt av Sikkerhetsrådet anbefalte at rådet henviste situasjonen til ICC (International Commission of Inquiry on Darfur 2005: para. 647). Sudan-saken er til nå den eneste situasjonen som har utløst en full folkemordsetterforskning, og Bashir ble tiltalt for folkemord i 2009 (ICC 2009).

Sudan har aldri vært medlem av ICC og har således ikke samtykket til domstolens jurisdiksjon. Der de 5 konfliktene som har vært henvist fra medlemsland er etterforsket med grunnlag i anerkjennelse fra henvisende stat, var Sudan-situasjonen dermed den første påtvungne etterforskningen ved ICC. Videre var Bashir en sittende statsleder da han ble siktet. Begge disse momentene grep rett inn i Sudans suverenitet og gjorde saken kontroversiell. Særlig siktelsen av Bashir endret afrikanske lands holdning til

\footnotetext{
${ }^{6}$ En innvending som har blitt fremmet mot de afrikanske landene som har henvist situasjoner til ICC, er at de bruker domstolen politisk til å straffeforfølge sine motstandsbevegelser. Disse påstandene er en interessant vinkling på hvordan regimer eventuelt bruker ICC til å fremme sine nasjonalpolitiske mål, men da artikkelen omfatter ICCs valg av situasjoner får det bli et tema for en annen artikkel. (Nouwen and Werner 2010) (Wilt 2015).
} 
domstolen (Mills 2012: 415). AU reagerte på ICCs arrestordre mot Bahir ved å be sine medlemsland i 2009 om å slutte å samarbeide med domstolen, samt be Sikkerhetsrådet i 2008 om å fryse ICCs etterforskning i Sudan (Tladi 2009: 61; Mills 2012: 420). Rådet har til nå valgt å se bort fra AUs anmodning om å legge Sudan-etterforskningen på is, og forholdet mellom afrikanske stater og domstolen har forvitret ytterligere siden 2009. Dette understrekes av Sør-Afrikas og AUs støtte til Bashir i 2015 og viser at flere afrikanske land fortsatt ikke er villige til å samarbeide med ICC om å få Bashir utlevert.

Sikkerhetsrådets henvisning av Sudan-situasjonen var utvilsomt kontroversielt vis-à-vis Afrika, men en slik politisk betraktning faller utenfor de forhold som skal inngå i sjefsanklagerens vurdering av hvorvidt en etterforskning skal åpnes. ${ }^{7}$ Forekomst av internasjonale forbrytelser er - i likhet med konflikter henvist fra medlemsland kriteriet som påtalemyndigheten skal legge til grunn når de vurdere en Sikkerhetsrådshenvendelse. Forbrytelsene i Darfur var grove og veldokumenterte allerede i 2005. Det hadde da sannsynligvis vært et brudd på Roma-vedtektenes formål dersom ICC hadde henlagt saken. Libya-situasjonen omfatter likedan påstander om alvorlige forbrytelser mot menneskeheten forvoldt av Gaddafi-regimet (ICC 2011c).

\section{Proprio motu}

Analysen til nå har belyst at de 7 etterforskningene som har blitt åpnet i kraft av henvendelser fra Sikkerhetsrådet og medlemsland, ikke egentlig kan regnes for å være valgt av ICC da påtalemyndigheten har vært pliktige til å etterforske disse konfliktene i tråd med Roma-vedtektene. Med tanke på en påstått afrikafiendtlighet i valg av etterforskninger fra domstolens side, står man da igjen med de to situasjonene som har blitt trigget av påtalemyndigheten.

Proprio motu er latinsk for «på eget initiativ» og er betegnelsen som Romavedtektene bruker for å beskrive når sjefsanklageren ved ICC velger å trigge en etterforskning på egenhånd. At en uavhengig og selvstendig sjefsanklager skulle ha makten til å igangsette sine egne etterforskninger var gienstand for mye debatt under Roma-konferansen (Schabas 2010: 315-318). Statene ble til slutt enige om en kompromissløsning hvor aktoratet kunne trigge etterforskninger, men bare dersom den godkjentes av forhørsdommerne. Således har ikke aktoratet ved ICC adgang til å igangsette en etterforskning helt på egenhånd. Dersom sjefsanklageren ønsker å etterforske en konflikt må hun søke om autorisasjon fra ICCs forhørskammer (Roma-vedtektene artikkel 15(3)). Denne kompromissløsningen var ment å forhindre at man fikk en 'aktivistisk' sjefsanklager som iverksatte politisk motiverte og

\footnotetext{
${ }^{7}$ Roma-vedtektenes artikkel 53(1)(c) gir sjefsanklageren adgang til å velge å ikke åpne en etterforskning i sitasjoner hvor «... det tas hensyn til forbrytelsens alvorlighetsgrad og ofrenes interesser, det likevel er vektige grunner til å tro at en etterforskning ikke ville være tjenlig ut fra rettferdighetshensyn.» Per 2016 har sjefsanklageren til gode å henlegge med bakgrunn i 'rettferdighetshensyn' og det er derfor uklart hva disse hensynene hadde vært i praksis. Det kan tenkes at politiske betraktninger kanskje kunne komme inn under rettferdighetshensynbegrepet, men ettersom det ikke har blitt tatt i bruk av påtalemyndigheten er det fortsatt uklart. Slike hensyn vil uansett være overprøvbare av forhørsdommerne. Ettersom 'rettferdighetshensyn' ikke er tatt i bruk i utvelgelse av konflikter i perioden 2002-2015, blir dette begrepet følgelig ikke drøftet i analysen.
} 
partiske straffesaker (Bergsmo \& Pejc 2008: 581-584). Forhørskammerets autorisasjon fungerer derfor som en kontrollmekanisme for å forsikre at påtalemyndighetens valg av situasjoner er i tråd med Roma-vedtektene.

Kenya-situasjonen var den første etterforskningen initiert i kraft av påtalemyndighetens proprio motu makt (ICC 2010b). Dette har også til nå utvilsomt vært den mest kontroversielle etterforskningen ved ICC. Det var særlig igangsettingen av denne etterforskningen som forsterket spliden mellom ICC og AU i etterkant av Sudan-saken. Kenya-situasjonen er kompleks og det er mye man kunne skrevet om den, spesielt om domstolens mangelfulle håndtering av selve etterforskningen. Men dersom man holder seg til en analyse av artikkelens tema - hvordan og hvorfor ICC valgte å åpne en etterforskning i Kenya-situasjonen - blir kenyanske samfunnsaktørers rolle i handlingsløpet et viktig element.

I korte trekk handler etterforskningen i Kenya om forbrytelser mot menneskeheten som fant sted i kjølevannet av Kenyas presidentvalg i desember 2007 (Hohn 2014). Da valgresultatet ble offentliggjort, førte anklager om valgfusk til en rekke voldelige sammenstøt mellom de politiske og til dels etniske fraksjonene i Kenya. I løpet av konflikten skal ca. 1100 mennesker ha blitt drept, 300.000 skadet og 600.000 internfordrevet (Mueller 2014: 27). Voldsepisodene førte til at FNs tidligere generalsekretær, Kofi Annan, ble oppnevnt av AU til å megle fred mellom de to politiske fraksjonene, og på bakgrunn av forliket dannet de to partiene en koalisjonsregjering $\mathrm{i}$ 2008 (Jalloh 2011: 541). Som en del av avtalen oppnevnte også den nye regjeringen en egen kommisjon som skulle granske voldshendelsene.

«Waki-kommisjonen» avla sin rapport i 2009 og anbefalte at Kenya burde opprette en egen spesialdomstol med mandat til å straffeforfølge de som var ansvarlige for valgvolden (Kriegler \& Waki 2009: 70). Parlamentet i Kenya nedstemte forslaget, noe som kanskje ikke er overaskende, ettersom de som er mistenkt for å ha vært initiativtagerne til volden er toppolitikere i Kenya (Jalloh 2011: 541). Waki-kommisjonen hadde forutsett en slik reaksjon fra politikeren i parlamentet og hadde gitt Kofi Annan en konfidensiell liste med navn på de personene som kommisjonen mistenkte var ansvarlige for valgvolden, med instruksjoner om at Annan skulle overlevere navnene og bevismaterialet til ICC dersom det kenyanske parlamentet ikke opprettet en spesialdomstol. I juli 2009 overleverte Annan navnene til ICC og uttalte at «[t]he people of Kenya want to see concrete progress on impunity. Without such progress, the reconciliation between ethnic groups and the longterm stability of Kenya is in jeopardy» (Rice 2009). Sjefsanklageren ved ICC søkte deretter om og fikk tillatelse fra forhørsdommerne til å åpne en etterforskning i Kenya-situasjonen (ICC 2010b).

En måte å betrakte Kenya-situasjonen på, er at det var Waki-kommisjonen gjennom Kofi Annan som sendte situasjonen til ICC. Sjefsanklageren har selvfølgelig ikke samme forpliktelsene til å åpne en etterforskning når det er andre samfunnsaktører som henvender seg til domstolen (og ikke medlemslandets regjering), men man kan heller ikke se bort fra betydningen av deres rolle. Med tanke på formålet til ICC, ville det også vært tankevekkende dersom påtalemyndigheten hadde avvist en direkte henvendelse om hjelp fra sivilsamfunnet i Kenya, særlig etter at kenyanske politikere nedstemte den eneste rettsmekanismen som ofrene for valgvolden hadde i Kenya. 
Den andre proprio motu situasjonen som var blitt åpnet innen utgangen av $2015 \mathrm{er}$ Elfenbeinskysten. Ser man nærmere på omstendighetene som førte til at sjefsanklageren valgte å åpne en etterforskning i nettopp denne saken, så spilte den nye regjeringen i landet en avgjørende rolle. Elfenbeinskysten var ikke medlem av ICC da sjefsanklageren søkte om å få åpne etterforskningen i 2011 (ICC $2011 \mathrm{a}$ : para. 10). Det er kun land som er statspart til Roma-vedtektene som har rett til å henvise sine egne situasjoner til domstolen. For land som ikke er medlemmer av domstolen, men som har gitt ICC midlertidig jurisdiksjon over en situasjon (slik Elfenbeinskysten gjorde allerede i 2003) er det sjefsanklagere som likevel må åpne etterforskningen. I likhet med Kenya omhandler konflikten i Elfenbeinskysten voldelige opptøyer som følge av et presidentvalg. I 2010 nektet den tidligere presidenten Laurent Gbagbo å gå av etter å ha tapt valget. En halv million mennesker skal ha blitt internfordrevet som et resultat av valgvolden og 3,000 mistet livet (James 2011).

I 2010 sendte den nye regjeringen i Elfenbeinskysten et offisielt brev til ICC, hvor de ba sjefsanklageren om å åpne en etterforskning i landet (Elfenbeinskysten 2010). ${ }^{8}$ Ettersom Elfenbeinskysten ikke var medlem av ICC, trigget ikke dette brevet en etterforskning. Således var det sjefsanklageren ved ICC som trigget etterforskningen i 2011. Men, ettersom det i slike situasjoner er landet som frivillig har gitt ICC hjemmel til å etterforske konflikten, samt formelt anmodet sjefsanklageren om å åpne en etterforskning, ligner disse tilfellene mer på en medlemslandshenvisning. Det blir derfor misvisende å kategorisere Elfenbeinskysten som en konflikt ICC har valgt helt på egenhånd; spesielt når Elfenbeinskysten har sendt flere offisielle brev til ICC hvor de ber domstolen etterforske situasionen i landet (ibid.). Undertegnedes analyse er således at selv om det formelt var påtalemyndigheten som valgte å åpne en etterforskning i Elfenbeinskysten og Kenya, var likevel enten landets myndigheter eller andre samfunnsaktører av avgjørende betydning for at konfliktene ble valgt.

\section{Har utvelgelsen av disse konfliktene vist en afrikaselektivitet?}

Den empiriske gjennomgangen av ICCs valg av konflikter har munnet ut $\mathrm{i}$ to konklusjoner: (i) De 7 konfliktene som har blitt åpnet i kraft av en medlemsland eller sikkerhetsrådshenvendelse kan ikke regnes for å være valgt av ICC, da sjefsanklageren har vært pliktig til å etterforske disse konfliktene i tråd med Roma-vedtektene. (ii) I de to konfliktene igangsatt av påtalemyndigheten har landets myndigheter eller sentrale samfunnsaktører vært avgiørende pådrivere for at aktoratet skulle åpne en etterforskning.

Ut ifra dette er det lite treffende å påstå at ICC har vist en afrikaselektivitet i praksis. Analysen avdekker imidlertid at ICC i liten grad har gått aktivt inn og valgt konfliktene som skulle etterforskes. Brorparten av situasjonene har havnet hos sjefsanklageren på bakgrunn av en henvendelse. Videre viser analysen at flertallet av situasjonene ved ICC (5 stykker) er der i kraft av en afrikansk medlemslandshenvendelse. Det er således

\footnotetext{
${ }^{8}$ Her kan man i likhet med situasjonene som har blitt henvist av medlemsland, bemerke at den nye presidenten Outtara tilsynelatende har brukt ICC for å få avsatt sin politiske motstander i presidentvalget. Dette bærer preg av seierherrens justis og er nok et interessant eksempel på hvordan afrikanske medlemsland bruker domstolen til å fremme sin nasjonale politiske agenda.
} 
afrikanske stater som i stor grad har benyttet seg av domstolen. Dette står i tydelig kontrast til oppfatningen av ICC som afrikafiendtlig.

Analysen i denne artikkelen har anvendt en juridisk og empirisk metode for å vurdere ICCs valg av konflikter. Eksisterende faglitteratur om ICC og Afrika har en tendens til å fokusere på hvorvidt domstolen blir brukt eller opptrer politisk og partisk etter at den har begynt å etterforske en situasjon (Nouwen \& Werner 2010; Branch 2007; Roach 2013; Udombana 2005). Politiseringen av ICC som institusjon idet den går inn og etterforsker afrikanske stater, er et svært spennende tema. Men ved å analysere ICC forhold til Afrika uten å tilstrekkelig forklare afrikanske staters og Sikkerhetsrådets utslagsgivende rolle $\mathrm{i}$ at konfliktene $\mathrm{i}$ det hele tatt blir etterforsket, risikerer man å politisere ICC ytterligere. På den andre siden finner man en del faglitteratur som tar for seg en mulig politisk utvelgelse av situasjoner ved å se på hvilket skjønn ICCs påtalemyndighet har i valg av konflikter, uten å koble dette tilstrekkelig til en empirisk analyse av hvordan domstolen faktisk har forvaltet skjønnet i praksis (Davis 2015; Goldston 2010; Greenawalt 2007; Schabas 2010). Som Smeulers et al. påpeker, er empiriske analyser av hvordan ICC utvelger konflikter en mangelvare i litteraturen (Smeulers, Weerdesteijn et al. 2015: 4).

Smeulers og hennes kolleger har skrevet en veldig interessant artikkel som går empirisk til verks for å evaluere aktoratets valg av konflikter i lys av alvorlighetsgraden til alle konfliktene i verden som var aktive i perioden 2002-2011. Konklusjonen til forfatteren er at dominansen av afrikanske konflikter kan forklares med at Afrika hadde hovedandelen av verdens mest alvorlige konflikter i denne perioden, samtidig som de fleste afrikanske land faller inn under jurisdiksjonen til ICC (Smeulers, Weerdesteijn et al. 2015: 39). Denne analysen måler således ICCs praksis opp mot alle de store konfliktene som teoretisk kunne kommet under mandatet til ICC i perioden 2001-2011. For å bidra til faglitteraturens empiriske analyse av ICC valg av konflikter, har denne artikkelen derfor valgt å se på domstolens valg av situasjoner i lys av de konkrete konfliktene som faktisk har blitt forsøkt trigget til etterforskning.

\section{En Passiv Selektivitet?}

Denne artikkelen hevder at en juridisk analyse av ICCs praksis om valg av situasjoner viser at domstolen ikke aktivt har utøvd et partisk valg av konflikter overfor afrikanske medlemsland. Men i likhet med måten det internasjonale samfunnet utpekte konfliktene som ble gjenstand for de midlertidig internasjonale straffedomstolene på 1990 og 2000-tallet, er spørsmålet om det er belegg for å hevde at ICC har vist en passiv selektivitet i valg av situasjoner. Som nevnt innledningsvis ble de midlertidige internasjonale straffedomstolene opprettet svært selektivt, sett i forhold til antallet lignende konflikter som ikke fikk tildelt slike domstoler. Det virker nesten selvsagt at verdenssamfunnet skulle opprette en internasjonal straffedomstol for å straffeforfølge folkemordet i Kambodsja, men mindre opplagt hvorfor Vietnamkrigen ikke har fått et lignende straffeoppgjør. Dette var da en slags passiv selektivitet hvor FN 
og Sikkerhetsrådet opprettet domstoler i konflikter som i liten grad berørte deres egne interesser.

Et interessant spørsmål er da om ICC har vist en lignende passiv konfliktselektivitet i lys av konfliktene som ikke har blitt åpnet for etterforskning. Har påtalemyndigheten, domstolens ikke-afrikanske medlemsland og Sikkerhetsrådet unnlatt å agere i lignende tilfeller av massevold utenfor Afrika?

\section{Ikke-afrikanske medlemsland}

Det ble påpekt under analysen av ICCs praksis at det kun er afrikanske land som har henvist konflikter til domstolen. Hvorfor har afrikanske stater vært villige til å sende sine konflikter til ICC i motsetning til land fra andre kontinenter? En mulig forklaring er at ICC er etablert på grunnlag av komplementaritetsprinsippet, som betyr at domstolen i prinsippet kun skal etterforske internasjonale forbrytelser som ikke er tatt hånd om av nasjonale myndigheter (Stigen 2008). Land som har et velutviklet rettssystem og har kapasitet til å straffeforfølge krigsforbrytelsene selv, vil da ikke ha samme behov for å sende sakene sine til ICC. Men komplementaritetsprinsippet alene er ikke en tilstrekkelig forklaring på hvorfor fem av situasjonene under innledende gransking i land som ligger utenfor Afrika, ikke har blitt henvist på initiativ fra medlemslandene.

Hverken Storbritannia (som er under innledende gransking i Irak-situasjonen), Colombia, Afghanistan, Palestina eller Georgia har valgt å henvise sine egne konflikter til ICC. Dette på tross av at sjefsanklageren ved domstolen har åpnet en innledende gransking i lys av troverdig informasjon som peker på at internasjonale forbrytelser kan ha funnet sted i løpet av disse konfliktene. Det at medlemsland lar være å henvise sine egne situasjoner til ICC, gjør arbeidet til påtalemyndigheten vanskeligere. Dette fordi påtalemyndigheten som nevnt må søke autorisasjon fra forhørsdommerne når de ønsker å åpne en etterforskning proprio motu. I en slik autorisasjonssøknad må sjefsanklageren bl.a. fremlegge bevis som sannsynliggiør at internasjonale forbrytelser er blitt forvoldt i konflikten. Således har påtalemyndigheten en ganske betydelig bevisbyrde når det er den som trigger situasjonen. Innhenting av bevis er både resurs- og tidskrevende for domstolen og noe som ikke kreves der det er medlemslandene som henviser saken selv.

Ikke-afrikanske medlemsland gjør med andre ord domstolens arbeid mer utfordrende ved å la være å trigge etterforskninger via henvendelser. Dersom ICC skal ha best mulig forutsetninger for å etterforske konflikter på en nøytral og upartisk måte er det derfor viktig at ikke-afrikanske medlemsland tar domstolen aktivt i bruk - på lik linje som afrikanske medlemsland - ved selv å henvise sine konflikter til ICC.

\section{Sikkerhetsrådet}

Som vist tidligere har brorparten av verdens stormakter og flere sikkerhetsrådsmedlemmer unnlatt å bli medlemmer av ICC. Det betyr at sikkerhetsrådshenvendelser bortimot er den eneste måten å bringe en stormakts-konflikt til ICC. Men praksisen så langt viser at Sikkerhetsrådet har vært tilbakeholden med å bruke sin henvisningsmyndighet. Geopolitiske interesser har tilsynelatende også spilt en stor rolle. 
Eksempelvis hindret Russland og Kina at Syria-konflikten ble sendt til ICC i 2014, ved å nedlegge veto (Black 2015). Tilstanden i Nord Korea ble i 2014 beskrevet som «Nazi-lignende» av lederen for en kommisjon nedsatt av FNs menneskerettighetsråd for å skrive en rapport om forbrytelser mot menneskeheten i landet (FNs menneskerettighetsråd 2014; Walker 2014). Rapporten førte til at FNs Generalforsamling fattet en ikke-bindende resolusjon i 2014, hvor de ba Sikkerhetsrådet om å sende Nord Korea-situasjonen til ICC. Men konflikten ble ikke sendt fordi Kina også i denne saken truet med å nedlegge veto (Al-Jazeera 2014). Før Palestina ble medlem av ICC i 2015, var USAs vetomakt hinderet som sto i veien for at Israel-Palestina konflikten kunne sendes til domstolen (Kersten 2014). ${ }^{9}$ Hvilke situasjoner rådet henviser til ICC ser således ut til å påvirkes i vesentlig grad av de utenrikspolitiske interessene til Kina, Russland og USA.

Denne passive selektiviteten til Sikkerhetsrådet fører nok en gang til at ICC også lider under den samme konfliktselektiviteten som de midlertidige internasjonale straffedomstolene, hvor det nærmest er umulig å få en konflikt som berører permanente medlemmer av rådet, eller deres interesser, sendt til en internasjonal straffedomstol. Når tre av rådsmedlemmene med vetomakt i tillegg ikke er medlem av domstolen - og tilsynelatende hemmer henvisningsmekanismen ved å fremme sine egne geopolitiske interesser - bør man tenke grundig gjennom hvor legitimt det er at disse landene skal ha rett til å sende andre lands konflikter til ICC.

\section{Påtalemyndigheten}

Sist men ikke minst, peker gjennomgangen av ICCs praksis på at også påtalemyndigheten ved domstolen har utøvd en form for passiv selektivitet. Etter 13 år med virksomhet viser analysen at domstolens sjefsanklager bare har igangsatt to etterforskninger på egenhånd, og $\mathrm{i}$ begge disse konfliktene var landets myndigheter eller samfunnsaktører viktige pådrivere i utvelgelsesprosessen. Dette i kontrast til at påtalemyndigheten hadde mottatt over 10,000 konfidensielle «kommunikasjoner» eller henvendelser med informasjon og bevis om internasjonale forbrytelser innen utgangen av 2013 (Office of the Prosecutor ICC 2015a). Det er vanskelig å forklare på en tilfredsstillende måte hvorfor påtalemyndigheten kun har åpnet to etterforskninger, når den har mottatt flere tusen kommunikasjoner fra sivile aktører med informasjon om forbrytelser. Påtalemyndigheten har tilsynelatende benyttet seg av sitt handlingsrom (som beskrevet i gjennomgangen av domstolens mandat) ved å være svært beskjeden i valg av nye konflikter.

Den passive konfliktselektiviteten vises spesielt i forskjellen mellom påtalemyndighetens handlinger i konfliktene under innledende gransking og konfliktene som er blitt åpnet for etterforskning. Som nevnt tidligere har påtalemyndigheten ved ICC iverksatt totalt 12 innledende granskinger; granskinger som hovedsakelig rommer politisk sensitive konflikter utenfor Afrika og som har hatt en tendens til å bli liggende

\footnotetext{
${ }^{9}$ Palestina ble medlem av ICC i 2015 og påtalemyndigheten ved domstolen har iverksatt en innledende gransking i situasjonen. Likevel reiser Palestinas usikre territorielle status en del juridiske problemstillinger som man hadde unngått ved en sikkerhetsrådshenvendelse (Høgestøl 2015).
} 
til innledende behandling over flere år. Ser man nærmer på konfliktene som for øyeblikket er under innledende gransking, gjelder flere av dem krevende etterforskninger mot mektige land som gjerne ikke er medlem av domstolen. Irak- og Afghanistan-situasjonene hadde eksempelvis nødvendiggjort etterforskning av diverse NATO-styrker, herunder tjenestepersoner fra Storbritannia og USA. Palestinasituasjonen hadde medført en etterforskning av israelere og palestinere, og både Georgia- og Ukraina-konfliktene involverer Russland. Det er nærliggende å tro at etterforskninger av de nevnte konfliktene hadde blitt svært krevende for domstolen. Men skal aktoratet ved ICC øke sin legitimitet i Afrika og resten av verden, må de også vise at de er i stand til å ta tak i disse politisk sensitive konfliktene, på lik linje som med en situasjon fra Afrika.

\section{Konklusjon: problemet med passiv selektivitet}

Som nevnt innledningsvis, kom ANC med en støtteerklæring til Bashir idet han flyktet fra Sør-Afrika i juni 2015, hvor de påpeker at afrikanske land «... unjustifiably bear the brunt of the decisions of the ICC with Sudan being the latest example.» (African National Congress 2015). Dersom analysen ovenfor stemmer og det er grunnlag for å tro at der eksisterer en passiv selektivitet i måten ICC etterforsker saker, så blir ANCs kritikk delvis treffende.

Artikkelen har argumentert for at ICC ikke har vært partisk overfor afrikanske land ut ifra de ni konfliktene som domstolen har valgt å etterforske. Men analysen tyder også på at der finnes indikasjoner på at ikke-afrikanske medlemsland, Sikkerhetsrådet og til dels også domstolens påtalemyndighet har agert passivt $i$ henhold til konflikter utenfor Afrika. Skal domstolen leve opp til sine forventinger om å være «... a truly international criminal tribunal ... with a potentially universal scope and charged with dispensing justice not on an ad hoc, i.e. selective basis» (Cassese 2006: 434), så må det tas grep for å sikre at ICC blir en domstol som etterforsker internasjonale forbrytelser, uavhengig av hvor forbrytelsene finner sted.

Samtidig må man også kunne være noe kritisk til Afrika-kritikken når den blir fremstilt av støttespillere til Omar al-Bashir. Ifølge New York Times skal Bashir ha vært en av de første som beskyldte ICC for å være afrikafiendtlig, etter at han ble siktet av domstolen for folkemord i 2009 (Onishi 2015). Kenyas president, Uhuru Kenyatta, har også vært en hyppig tilhenger av kritikken og var en pådriverne for at medlemsstatene i Den afrikanske unionen i 2013 skulle trekke seg fra ICC en masse (BBC 2013). Men Kenyatta har også vært siktet av ICC for forbrytelser mot menneskeheten (ICC 2011b). Det er vanskelig å ta kritikk på alvor når den blir fremmet av afrikanske ledere som selv risikerer å bli dømt av ICC for grove internasjonale forbrytelser.

Det er da urovekkende at land som Sør-Afrika nå vurderer å trekke seg fra ICC, for å støtte opp om afrikanske ledere som er siktet av domstolen. Bashir er tross alt beskylt for å være ansvarlig for folkemord på en afrikansk etnisk minoritetsgruppe i Darfur i 2005. Sudan har blitt beskyldt for å ha et apartheidliknende styre i Darfur og det som i dag utgiør Sør-Sudan, der den arabiske majoriteten skal ha undertrykt 
samtlige afrikanske minoritetsgrupper (Asante 2012). Det er nedslående at ANC, Nelson Mandelas parti, nå er med på å støtte opp om et slikt regime. Sør-Afrika har tilsynelatende valgt å prioritere sine utenrikspolitiske interesser fremfor å bistå ICC med å straffeforfølge Bashir. Dersom flere afrikanske land velger å følge SørAfrikas eksempel, vil dette ytterligere svekke ICCs posisjon i regionen. Bashir-saken understreker således at det nå er helt essensielt for ICC å endre inntrykket av domstolen som afrikafiendtlig, slik at afrikanske ledere ikke lenger kan bruke kritikken som et skalkeskjul for å unndra seg straffeansvar for massevold.

\section{Postskript: Georgia-situasjonen}

Man kan spekulere i om Afrika-kritikken spilte en rolle da påtalemyndigheten ved ICC leverte en søknad 16. oktober 2015 om autorisasjon til å åpne en etterforskning i Georgia-situasjonen (ICC 2015b). Forhørsdommerne godkjente søknaden i januar 2016 og ICC har da endelig, etter 14 år med virksomhet, fått sin første etterforskning utenfor Afrika. Det gjenstår å se om åpningen av Georgia-situasjonen vil ha en positiv innvirkning på ICCs forhold til sine afrikanske medlemsland.

\section{Om artikkelen}

Jeg er takknemlig for kommentarer og innspill fra Thomas Frøberg og gode stipendiatkollegaer Anna Andersson, Stian Øby Johansen og Sondre Torp Helmersen; og Tomm Kristiansen ved NRK for inspirasjonen.

\section{Litteraturliste}

2009. The Prosecutor v. Omar Hassan Ahmad Al Bashir (ICC-02/05-01/09-1). International Criminal Court. 2010a. Closing Order (Indictment) in Case 002 (D427). Extraordinary Chambers in the Courts of Cambodia. 2010b. Decision Pursuant to Article 15 of the Rome Statute on the Authorization of an Investigation into the Situation in the Republic of Kenya (ICC-01/09-19). International Criminal Court.

2011a. Decision Pursuant to Article 15 of the Rome Statute on the Authorisation of an Investigation into the Situation in the Republic of Côte d'Ivoire (ICC-02/11-14). International Criminal Court.

2011b. The Prosecutor v. Francis Kirimi Muthaura, Uhuru Mugiai Kenyatta and Mohammed Hussein Ali (ICC-01/09-02/11). International Criminal Court.

2011c. Prosecutor v. Mohammed Abu Minyar Gaddafi, Saif Al-Islam Gaddafi and Abdullah Al-Senussi (ICC01/11). International Criminal Court.

2015a. Decision on the Request of the Union of Comoros to Review the Prosecutor's Decision Not to Initiate An Investigation (ICC-01/13). International Criminal Court.

2015b. Request for Autorisation of An Investigation Pursuant to Article 15 (ICC-01/15-4-Corr). International Criminal Court.

African National Congress (2015) «ANC Statement on High Court Order on President Al-Bashir» 14.06.2015.

Al-Jazeera (2014) «UN Assembly Votes to Refer North Korea to ICC» 19.12.2014.

Al-Jazeera (2015) «Sudan's Bashir Leaves South Africa Despite Court Order» 15.06.2015.

Asante, Molet Kete (2012) «Arab Racism Raises its Head in Sudan.» Tilgjengelig på http://www.asante.net/ articles/52/afrocentricity/ Lesedato 02.05.2016.

Bass, Gary Jonathan (2000) Stay the Hand of Vengance: the Politics of War Crimes. Princetion: Princeton University Press.

BBC (2013) «African Union Summit on ICC Pullout Over Ruto Trial» 20.09.2013. 


\section{Er Den internasjonale straffedomstolen afrikafiendtlig?}

Bergsmo, Morten \& Jelena Pejic (2008) «Article 15» i Otto Triffterer (red.) Commentary on the Rome Statute of the International Criminal Court. Munchen: C. H. Beck (581-594).

Black, Ian (2015) «Russia and China Veto UN Move to Refer Syria to International Criminal Court» The Guardian 22.05.2014.

Bowcott, Owen (2015) «Sudan President Omar al-Bashir Leaves South Africa as Court Considers Arrest» The Guardian 15.06.2015.

Branch, Adam (2007) «Uganda's Civil War and the Politics of ICC Intervention», Ethics E International Affairs, 21 (2): 179-198.

Burke-White, William W. (2005) «Complementarity in Practice: the International Criminal Court as Part of a System of Multi-Level Global Governance in the Democratic Republic of Congo», Leiden fournal of International Law, 18 (3): 557-590.

Campell, Greg (2004) Blood Diamonds: Tracing the Deadly Path of the Wrold's Most Precious Stones. New York: Basic Books.

Cassese, Antonio (2006) «Is the ICC Still Having Teething Problems?», fournal of International Criminal fustice, 4 (3): 434-441.

Chigara, Benedict Abrahamson \& Chidebe Matthew Nwankwo (2015) “'To be or not to be?' The African Union and its Member States Parties' Participation as High Contracting States Parties to the Rome Statute of the International Criminal Court (1998)», Nordic fournal of Human Rights, 33 (3): 243-268.

Davis, Cale (2015) «Political Considerations in Prosecutorial Discretion at the International Criminal Court», International Criminal Law Review, 15 (1):170-189.

DeGuzman, Margaret M. (2012) «Choosing to Prosecute: Expressive Selection at the International Criminal»

Det internasjonale tribunalet for straffeforfølgelse av personer ansvarlige for alvorlige brudd på internasjonal humanitær lov begått på territoriet til det tidligere Jugoslavia siden 1991 (ICTY) vedtekter, vedtatt av FNs sikkerhetsrådsresolusjon S/RES/827 25.05.1993.

Elfenbeinkysten (2010) «Letter reconfirming the acceptance of the ICC jurisdiction». Tilgjengelig på https:// www.icc-cpi.int/NR/rdonlyres/498E8FEB-7A72-4005-A209-C14BA374804F/0/ReconCPI.pdf. Lesedato 02.05.2016.

FNs menneskerettighetsråd A/HRC/25/63 «Report of the Commission of Inquiry on Human Rights in the Democatic People's Republic of Korea» 07.02.2014.

FNs generalforsamlingsrapport A/69/321 «Report of the International Criminal Court» 18.09.2014.

FNs sikkerhetsrådrapport S/2014/928 «Report of the International Commission of Inquiry on the Central African Republic» 22.12.2014.

FNs sikkerhetsrådsresolusjon 1593 (2005) S/RES/1593. 31.03.2005.

Gilbert, G.M. (1947) Nuremberg Diary. New York: Farrar Straus.

Gisle, Jon (2009) «Jurisdiksjon» i Store Norske Leksikon 12.06.2009.

Goldston, James A. (2010) «More Candour About Criteria: The Exercise of Discretion by the Prosecutor of the International Criminal Court», fournal of International Criminal fustice, 8 (2): 383-406.

Greenawalt, Alexander K. A. (2007) «Justice Without Politics? Prosecutorial Discretion and the International Criminal Court», NYU fournal of International Law and Politics, 39: 583-673.

Greenawalt, Alexander K. A. (2009) "Complementarity in Crisis: Uganda, Alternative Justice, and the International Criminal Court», Virginia fournal of International Law, 50 (1): 107-162.

Gullikstad, Åsne (2015) «Nytt slag for ICC» Dagsavisen 16.06.2015.

Hohn, Sabine (2014) «New Start or False Start? The ICC and Electoral Violence in Kenya», Development and Change, 45 (3): 565-588.

Høgestøl, Sofie (2015) «Palestinian Membership of the ICC: A Preliminary Analysis», Nordic fournal of Human Rights, 33 (3): 193-202.

ICC (2004) President of Uganda refers situation concerning the Lord's Resistance Army (LRA) to the ICC. Tilgjengelig på https://www.icc-cpi.int/en_menus/icc/press and media/press releases/2004/Pages/pre sident of uganda refers situation concerning the lord_s resistance army _lra_ to the icc.aspx. Lesedato 02.05 .2016

ICC (2016) The States Parties to the Rome Statute. Tilgjengelig på https://www.icc-cpi.int/en_menus/asp/ states parties/Pages/the states parties to the rome statute.aspx. Lesedato 01.03.2016.

International Commission of Inquiry on Darfur (2005) «Report of the International Commission of Inquiry on Darfur to the United Nations Secretary-General Geneva». Tilgjengelig på http:/www.un.org/news/dh/ sudan/com_inq_darfur.pdf. Lesedato 02.05.2016.

Jakobssen, Niklas (2015) «The 2016 ICC Budget - More Money, More Problems?» Tilgjengelig på https:// justicehub.org/article/2016-icc-budget-more-money-more-problems. Lesedato 02.05.2016. 


\section{Sofie A. E. Høgestøl}

Jalloh, Charles Chernor (2009) «Regionalizing International Criminal Law?», International Criminal Law Review, 9 (3): 445-499.

Jalloh, Charles Chernor (2011) «Situation in the Republic of Kenya», American fournal of International Law, 105 (3): 540-547.

James, John (2011) «Gbagbo Transfered to The Hauge Shocks Supporters» BBC Africa 30.11.2011.

Jia, Bing Bing (2006) «China and the International Criminal Court: Current Situation», Singapore Year Book of International Law, 10: 87-97.

Kersten, Mark (2014) "The Security Council's Appalling Record of Referring Situations to the ICC». Tilgjengelig på http://justiceinconflict.org/2014/05/23/the-security-councils-appalling-record-of-referringsituations-to-the-icc/. Lesedato 02.05.2016.

Komorene (2013) «Referral under Articles 14 and 12(2)(a) of the Rome Statute arising from the 31 May 2010 , Gaza Freedom Flotilla situation». Tilgjengelig på https://www.icc-cpi.int/iccdocs/otp/Referral-fromComoros.pdf. Lesedato 02.05.2016.

Kriegler and Waki (2009) «Kriegler and Waki Reports, Summarised Version, Revised Edition». Tilgjengelig på http://www.kas.de/wf/doc/kas_16094-1522-2-30.pdf. Lesedato 02.05.2016.

Mali (2012) «Renvoi de la situation au Mali». Tilgjengelig på https:/www.icc-cpi.int/NR/rdonlyres/A245A47FBFD1-45B6-891C-3BCB5B173F57/0/ReferralLetterMali130712.pdf. Lesedato 02.05.2016.

Maunganidze, Ottilia Anna \& Anton du Plessis (2015) «The ICC and the AU» i Carstein Stahn (red.) The Law and Practice of the International Criminal Court. Oxford: Oxford University Press (65-83).

Mills, Kurt (2012) «Bashir is Dividing Us: Africa and the International Criminal Court», Human Rights Quarterly, 34 (2): 404-447.

Mueller, Susanne D. (2014) «Kenya and the International Criminal Court (ICC): Politics, the Election and the Law», Fournal of Eastern African Studies, 8 (1): 25-42.

Musker, Saul (2015) «Why South Africa is Wrong to Leave the International Criminal Court» The Guardian 14.10 .2015 .

Ngaruko, Floribert \& Janvier D. Nkurunziza (2005) «Civil War and Its Duration in Burundi» i Paul Collier \& Nicholas Sambanis (red.) Understanding Civil War: Evidence and Analysis. Washington D.C.: The World Bank (35-61).

Nouwen, Sarah M. H. \& Wouter G. Werner (2010) «Doing Justice to the Political: The International Criminal Court in Uganda and Sudan», European Fournal of International Law, 21 (4): 941-965.

Office of the Prosecutor ICC (2014a) «Report on Preliminary Examination Activities 2014». Tilgjengelig på https://www.icc-cpi.int/iccdocs/otp/OTP-Pre-Exam-2014.pdf, Lesedato 02.05.2016.

Office of the Prosecutor ICC (2014b) «Situation on Registered Vessels of Comoros, Greece and Cambodia: Article 53(1) Report». Tilgjengelig på https://www.icc-cpi.int/iccdocs/otp/OTP-COM-Article_53(1)Report-06Nov2014Eng.pdf. Lesedato 02.05.2016.

Office of the Prosecutor ICC (2015a) Preliminary Examinations. Tilgjengelig på http://www.icc-cpi.int/en menus/icc/structure of the court/office of the prosecutor/comm and ref/Pages/communications and referrals.aspx. Lesedato 01.01.2016

Office of the Prosecutor ICC (2015b) «Report on Preliminary Examination Activites 2015». Tilgjengelig på https:/www.icc-cpi.int/iccdocs/otp/OTP-PE-rep-2015-Eng.pdf. Lesedato 02.05.2016

Olásolo, Héctor (2005) The Triggering Procedure of the International Criminal Court. Leiden: Martinus Nijhoff Publishers.

Onishi, Norimitsu (2015) «Bid by Omar al-Bashir of Sudan to Avoid Arrest Is Tested in South Africa» New York Times 14.06.2015.

Rice, Xan (2009) «Annan Hands ICC List of Perpetrators of Post-Election Violence in Kenya» The Guardian 09.07.2009.

Roach, Steven C. (2013) «How Political Is the ICC? Pressing Challenges and the Need for Diplomatic Efficacy», Global Governance, 19 (4): 507-523.

Roma-vedtektene (1998) signert 17.07.1998, i kraft 01.07.2002.

Schabas, William A. (2010) «Victor's Justice: Selecting "Situations" at the International Criminal Court», The fohn Marshall Law Review, 43 (3): 535-552.

Schabas, William A. (2015) «Selecting Situations and Cases» i Carsten Stahn (red.) The Law and Practice of the International Criminal Court. Oxford: Oxford University Press (365-381).

Scheffer, David (2012) All the Missing Souls: a Personal History of the War Crimes Tribunals. Princetion: Prinecton University Press.

Scheffer, David J. (1999) «The United States and the International Criminal Court», The American fournal of International Law, 93 (1): 12-22. 
Smeulers, Alette, Maartje Weerdesteijn \& Barbora Hola (2015) «The Selection of Situations by the ICC: An Empirically Based Evaluation of the OTP's Performance», International Criminal Law Review, 15 (1): 1-39.

Stigen, Jo (2008) The Relationship Between the International Criminal Court and National furisdictions: the Principle of Complementarity. Leiden: Brill.

The United Nations Conference of Plenipotentiaries on the Establishment of an International Criminal Court (1998) Rome, 15.06.1998- 17.06.1998.

Tisdall, Simon (2015) «Omar al-Bashir Case Suggests South African Foreign Policy is Going Rogue» The Guardian 15.06.2015.

Tladi, Dire (2009) «The African Union and the International Criminal Court: The Battle for the Soul of International Law», South African Yearbook of International Law, 34: 57-69.

Udombana, Nsongurua J. (2005) «Pay Back Time in Sudan? Darfur in the International Criminal Court», Tulsa fournal of Comparative and International Law, 13 (1): 1-58.

Walker, Peter (2014) «North Korea Human Rights Abuses Resemble Those of the Nazis, Says UN Inquiry» The Guardian 18.02.2014.

Wilt, Harmen van der (2015) «Self-Referrals as an Indication of the Inability of States to Cope with Non-State Actors» i Carstein Stahn (red.) The Law and Practice of the International Criminal Court. Oxford: Oxford University Press (210-227). 